\title{
MYOGLOBINS - THE LINK BETWEEN DISCOLORATION AND LIPID OXIDATION IN MUSCLE AND MEAT
}

\author{
Jens K. S. Møller* \\ Instituto de Química, Universidade Estadual de Campinas, PO Box 6154, 13084-971 Campinas - SP, Brazil; Royal Veterinary \\ and Agricultural University, Department of Food Science, Food Chemistry, Rolighedsvej 30, DK-1958 Frederiksberg C, Denmark \\ Leif H. Skibsted \\ Royal Veterinary and Agricultural University, Department of Food Science, Food Chemistry, Rolighedsvej 30, DK-1958 \\ Frederiksberg C, Denmark
}

Recebido em 9/1/05; aceito em 9/12/05; publicado na web em 6/7/06

\begin{abstract}
Aerobic metabolism changes rapidly to glycolysis post-mortem resulting in a $\mathrm{pH}$-decrease during the transformation of muscle in to meat affecting ligand binding and redox potential of the heme iron in myoglobin, the meat pigment. The "inorganic chemistry" of meat involves (i) redox-cycling between iron(II), iron(III), and iron(IV)/protein radicals; (ii) ligand exchange processes; and (iii) spin-equilibra with a change in coordination number for the heme iron. In addition to the function of myoglobin for oxygen storage, new physiological roles of myoglobin are currently being discovered, which notably find close parallels in the processes in fresh meat and nitrite-cured meat products. Myoglobin may be characterized as a bioreactor for small molecules like $\mathrm{O}_{2}, \mathrm{NO}$, $\mathrm{CO}, \mathrm{CO}_{2}, \mathrm{H}_{2} \mathrm{O}$, and $\mathrm{HNO}$ with importance in bio-regulation and in protection against oxidative stress in vivo otherwise affecting lipids in membranes. Many of these processes may be recognised as colour changes in fresh meat and cured meat products under different atmospheric conditions, and could also be instructive for teaching purposes.
\end{abstract}

Keywords: myoglobin complexes; heme iron; oxidative processes.

\section{INTRODUCTION}

The primary physiological role of the small iron-containing globular protein, myoglobin $(\mathrm{Mb})$, in mammals has been considered to maintain oxygen supply in skeletal muscles and other muscle tissue, where $\mathrm{Mb}$ acts in oxygen storage and the facilitated diffusion of molecular oxygen. ${ }^{1}$ New studies, however, strongly support other physiological roles of $\mathrm{Mb}$ in mammals. ${ }^{2-4} \mathrm{Mb}$ has served as a model molecule for other larger and more complex metalloproteins over the years, and experimental findings for $\mathrm{Mb}$ have been useful for generalization in relation to molecular structure, ${ }^{5}$ biophysics and mechanism of enzyme activation. ${ }^{6 ; 7}$ Apart from the physiological function of $\mathrm{Mb}$ and its role as a model for other macromolecules, the chemistry of $\mathrm{Mb}$ is important in food technology as the colour of both fresh meat and meat products depends on the redox status of the heme iron center.;

$\mathrm{Mb}$ is a small globular protein with about 150 amino acid residues and molecular weight of approx. $17 \mathrm{kD} .{ }^{10} \mathrm{~A}$ porphyrin ring, protoporphyrin IX, is partly buried in the interior of $\mathrm{Mb}$ and a central iron atom is coordinated to this prosthetic group forming a heme moiety, which constitutes the active site of the molecule. The protein backbone and the prosthetic group are attached by a single coordinative bond between the His94 residue and the heme iron, while hydrophobic interactions between vinyl side chains of the prosthetic group and hydrophobic amino acid residues in the interior of $\mathrm{Mb}$ also helps to stabilize the association.

This present review covers mainly the chemistry behind the colour and colour changes of fresh meat and meat products during processing and storage. The "inorganic chemistry" of meat will be discussed in relation to the coordination properties of the central heme iron atom in $\mathrm{Mb}$ and its redox chemistry. The redox chemistry of $\mathrm{Mb}$ and other heme proteins will also be discussed in relation to oxidative pro-

*e-mail: jemo@kvl.dk cesses occurring in muscle during transformation to meat and during meat curing, and these processes may cause deterioration of freshness and initiate lipid oxidation leading to rancidity.

\section{CHEMISTRY OF HEME IRON CENTRE IN MYOGLOBINS}

Under most physiological conditions, the iron atom in Mb and other heme proteins exists in either the ferrous(II) or the ferric(III) state with six or five electrons in the $3 \mathrm{~d}$ orbital available for bonding ( $\mathrm{d}^{6}$ or $\mathrm{d}^{5}$ electron configuration). ${ }^{9}$

The relatively high numbers of electrons present in the $3 \mathrm{~d}$ orbital makes several different electronic configurations possible for the iron complex with small differences in electronic energy. ${ }^{8}$ Low spin $\mathrm{Fe}^{\mathrm{II}}$ complexes are diamagnetic, while all other spin states of both $\mathrm{Fe}^{\mathrm{II}}$ and $\mathrm{Fe}^{\mathrm{III}}$ contain at least one unpaired electron.

Ligands are ordered according to increasing "field strength" in what is known as the spectrochemical series depending on their effect on the splitting $(\Delta)$ between $\mathrm{t}_{2 \mathrm{~g}}$ and $\mathrm{e}_{\mathrm{g}}$ orbitals: ${ }^{11}$

$\mathrm{I}^{-}<\mathrm{Br}^{-}<\mathrm{Cl}^{-}<\mathrm{SCN}^{-}<\mathrm{F}^{-}<\mathrm{OH}^{-}<\mathrm{H}_{2} \mathrm{O}<\mathrm{NCS}^{-}<\mathrm{NO}_{2}^{-}<\mathrm{CN}^{-} \approx \mathrm{CO}$

Thus, weak field ligands such as the halides favour high spin states as these ligands only participate in $\sigma$-bonding, while strong field ligands like $\mathrm{O}_{2}$, $\mathrm{NO}$ and $\mathrm{CN}^{-}$favour low spin state complexes with electron pairing of the $\mathrm{d}$ orbitals of iron. ${ }^{9 ; 12}$ Thus, the bond formation between the central metal and a strong field ligand may be considered to consist of two components: i) donation of $\sigma$-type electron density from the ligand to the central metal, and ii) donation of electron density from the $\mathrm{d}$ orbitals of the metal into the $\pi^{*}$-antibonding of the ligand referred to as "back-bonding". ${ }^{13}$ Regarding to physiologically relevant ligands, it has been pointed out that the rate of ligand association to heme iron(II) follows the order of the $\pi$-electron accepting abilities of the ligands, e.g. $\mathrm{NO}>\mathrm{O}_{2} \geq \mathrm{CO}^{8}$ 


\section{METAL LIGAND ELECTRONIC DISTRIBUTION}

Myoglobin heme iron has strong affinity for $\pi$-accepting ligands such as NO. ${ }^{13}$ Diatomic ligands like $\mathrm{NO}$ and $\mathrm{O}_{2}$ exist in different resonance forms, These ligands form complexes with transition metals that exhibit different electronic distributions, which besides the number of electrons in the complex are also affected by a varying degree of electronegativity of the diatomic ligands. Figure 1 shows examples of bonding geometry and electronic resonance forms for complexes of $\mathrm{Fe}^{\mathrm{II}}$ heme and three diatomic ligands of physiological importance. The different interactions between heme iron and ligands are due to differences in the dipole moment and other electronic properties. Thus, distribution of charge along the ligand or ionic character of the ligand greatly affects the ability to participate in hydrogen bonding with the amino acid residue, His64, in the distal heme pocket of $\mathrm{Mb}$, which accordingly also influences the stabilization of the metal ligand complex.

The notation for nitrosyl complexes incorporating bonding, bond geometry and reactivity developed by Enemark and Feltham has generally been accepted to predict the bonding geometry. ${ }^{12}$ The $\mathrm{d}$ orbital electrons of the metal and the $\pi^{*}$ orbital electrons from the ligand together are counted as the overall number of electrons in the complex, and the nitrosylated complexes of $\mathrm{Fe}^{\mathrm{III}}$ or $\mathrm{Fe}^{\mathrm{II}} \mathrm{Mb}$ can be written as $\{\mathrm{Fe}(\mathrm{NO})\}^{6}\left[\mathrm{Fe}\left(\mathrm{d}^{6-1}\right)+1 \pi^{*}\right.$ electron $]$ and $\{\mathrm{Fe}(\mathrm{NO})\}^{7}$ $\left[\mathrm{Fe}\left(\mathrm{d}^{6}\right)+1 \pi^{*}\right.$ electron], respectively, and used to predict the $\mathrm{Fe}-\mathrm{N}$ $\mathrm{O}$ bond angel, as linear for the $\mathrm{Fe}^{\mathrm{III}}$ complex and bent for the $\mathrm{Fe}^{\mathrm{II}}$ complex, respectively.
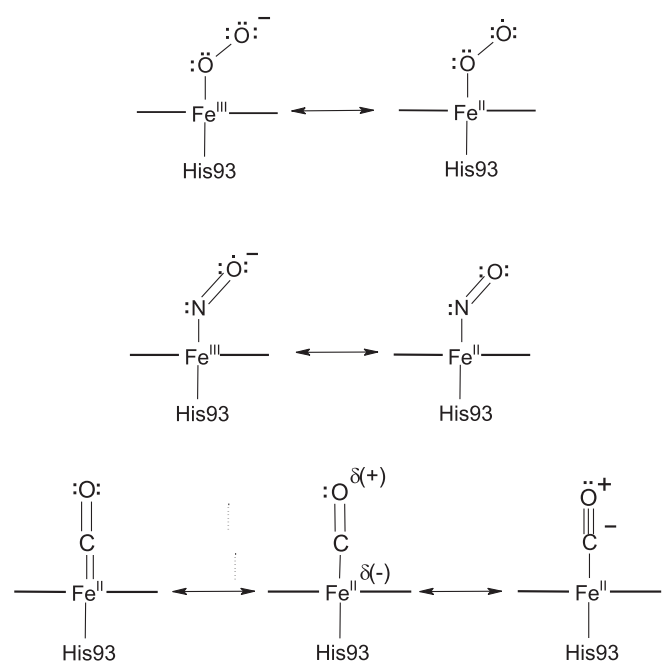

Figure 1. Fe-ligand bonding geometry and simplified electronic distribution for ferrous myoglobin complexes of $\mathrm{NO}, \mathrm{O}_{2}$ and $\mathrm{CO}$. Modified from refs. 8 and 13

\section{LIGAND BINDING AND DISCRIMINATION BY MYOGLOBIN}

A wide range of ligands form complexes with either ferrous or ferric $\mathrm{Mb}$ in muscle and meat. The small diatomic molecules $\mathrm{O}_{2}$, $\mathrm{NO}$ and $\mathrm{CO}$ all bind reversibly as axial ligand in the sixth position of ferrous $\mathrm{Mb}$, although their affinity for $\mathrm{Mb}$ varies significantly despite their similarities regarding size, charge and hydrophobicity. ${ }^{14}$ ${ }^{16} \mathrm{Mb}$ complexes with $\mathrm{NO}$ or $\mathrm{O}_{2}$ differ from the complex formed with $\mathrm{CO}$ regarding the ability to attain ionic character of the ligand due to variation in dipole moment, and also with respect to iron ligand bonding geometry of the complexes, Figure 1 . The complexes
$\mathrm{MbFe}^{\mathrm{II}} \mathrm{NO}$ and $\mathrm{MbFe}^{\mathrm{II}} \mathrm{O}_{2}$ have a bent ligand geometry $\left(112-147^{\circ}\right),{ }^{17 ; 18}$ whereas $\mathrm{MbFe}^{\mathrm{II}} \mathrm{CO}$ has been found (somewhat depending on the technique applied) to exhibit virtually a linear ligand geometry (155$\left.180^{\circ}\right) .{ }^{19}$ Several non-heme iron nitrosyl complexes exist and especially nitroprusside, $\left[\mathrm{Fe}(\mathrm{CN})_{5} \mathrm{NO}\right]^{3-}$, has been studied as the reactions of nitroprusside mimic the reactivity of metallonitrosyl in physiological environments. ${ }^{20}$ The geometry of the ground-state (structure I) has a typical low-spin character with a $\mathrm{Fe}-\mathrm{NO}^{+}$core and stronger $\pi$-back bonding to $\mathrm{NO}$ relative to the trans $\mathrm{CN}^{-}$resulting in a slight displacement of the iron towards the NO ligand, but still the short Fe-NO bond is linear rather than bent. Following photoexcitation of nitroprusside linkage isomers have been found, e.g. a linear oxygen bound isonitrosyl (structure II) and a side-on complex with NO bound sideways (structure III). ${ }^{21}$ Such isomers may also exist in nitrosylated heme protein and alter the reactivity of the heme Fe-NO complex, e.g. during photo-induced degradation of the nitrosylmyoglobin in meat products.

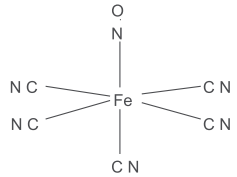

ground state

(1)

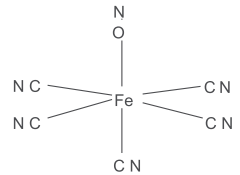

isonitrosy

(2)

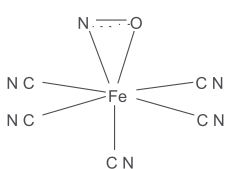

side-on

(3)
The differences in ligand geometry have been used to explain variation in ligand affinity for $\mathrm{Mb}$, and the observed bond geometries can be assigned either to variations in electrostatic interaction between ligand and amino acid residues or to steric hindrance in the heme pocket. In Table 1, rate constants for ligand association, ligand dissociation and equilibrium constants for binding of various ligands to $\mathrm{Mb}$ or heme models are summarized. NO forms the most stable complexes with ferrous $\mathrm{Mb}$, while $\mathrm{CO}$ has a significantly lower affinity for $\mathrm{Mb}$ closely followed by $\mathrm{O}_{2}$. However, studies with site-directed mutants of $\mathrm{Mb}$ suggest that the most important factor for overall stability of complexes of $\mathrm{Mb}$ is the ability to interact with hydrogen in His64, whereas steric hindrance of this residue is of minor significance. ${ }^{16}$ Moreover, the variation in stability observed for $\mathrm{MbFe}^{\mathrm{II}} \mathrm{NO}$ and $\mathrm{MbFe}^{\mathrm{II}} \mathrm{O}_{2}$ can be partly assigned to differences in the rate of bond formation between different ligands and heme iron. NO exhibits practically no energy barrier for bond formation, whereas the bond formation with $\mathrm{O}_{2}$ involves an energy barrier roughly equal to the energy for ligand escape from the heme pocket. ${ }^{14}$

Not surprisingly, the dynamic of recombination between heme iron and diatomic ligands, e.g. $\mathrm{NO}, \mathrm{CO}, \mathrm{O}_{2}$, depends on the presence or absence of the globin protein. ${ }^{22}$ This is further reflected in the differences in the binding constants observed for heme-containing proteins and various modified heme model compounds (see Table 1).

Several studies indicate that coordination of NO to heme iron weakens the fifth coordination position with proximal His93. ${ }^{23}$ In addition, lowering of $\mathrm{pH}$ will further induce weakening or breaking of the proximal base coordinated to iron. Thus, Duprat et al. have found that when coordination between proximal His 93 and heme iron is absent due to low $\mathrm{pH}$ or site-directed mutagenesis, the recombination rate of $\mathrm{NO}$ and heme iron is very fast resulting in a penta-coordinated state that is 3-fold more stable compared to NO bound in hexacoordinated $\mathrm{Mb}^{24,25}$ This transformation from a hexa- to pentacoordinated NO complex is of biological relevance in heme proteins such as soluble guanylate cyclase, ${ }^{26 ; 27}$ and flavo-heme enzymes, like Nitric Oxide Synthases (NOS). ${ }^{28}$ 
Table 1. Rate constants for ligand association $\left(\mathrm{k}_{\mathrm{ass}}\right)$ and ligand dissociation $\left(\mathrm{k}_{\mathrm{diss}}\right)$ together with equilibrium constant $\left(\mathrm{K}_{\mathrm{eq}}\right)$ for ligand binding to ferrous and ferric heme proteins and model compounds

\begin{tabular}{|c|c|c|c|c|c|c|}
\hline Iron Species & Ligand & $\mathrm{k}_{\text {ass }}\left(\mathrm{M}^{-1} \mathrm{~s}^{-1}\right)$ & $\mathrm{k}_{\mathrm{diss}}\left(\mathrm{s}^{-1}\right)$ & $\mathrm{K}_{\mathrm{eq}}\left(\mathrm{M}^{-1}\right)$ & Experimental Conditions & Ref. \\
\hline \multirow[t]{3}{*}{ FerrousMb } & $\mathrm{O}_{2}$ & $1.4 \times 10^{7}$ & 10 & $1.4 \times 10^{6}$ & Phosphate, $\mathrm{pH} 7.0,20{ }^{\circ} \mathrm{C}$ & 15 \\
\hline & $\mathrm{NO}$ & $1.7 \times 10^{7}$ & $1.2 \times 10^{-4}$ & $1.4 \times 10^{11}$ & Phosphate, $\mathrm{pH} 7.0,20{ }^{\circ} \mathrm{C}$ & 16 \\
\hline & $\mathrm{CO}$ & $5.1 \times 10^{5}$ & 0.019 & $2.7 \times 10^{7}$ & Phosphate, $\mathrm{pH} 7.0,20{ }^{\circ} \mathrm{C}$ & 15 \\
\hline \multirow[t]{4}{*}{ FerricMb } & NO & $1.9 \times 10^{5}$ & 13.6 & $1.4 \times 10^{4}$ & $\mathrm{H}_{2} \mathrm{O}, \mathrm{pH} 6.5,25^{\circ} \mathrm{C}$ & 22 \\
\hline & $\mathrm{HF}$ & $4.7 \times 10^{4}$ & 2 & $2.4 \times 10^{4}$ & Acetate, $\mathrm{pH} 4.5,25^{\circ} \mathrm{C}$ & 29 \\
\hline & $\mathrm{F}^{-}$ & $5.6 \times 10^{-2}$ & $8.7 \times 10^{-4}$ & 64 & Glycine, $\mathrm{pH} 11.0,25^{\circ} \mathrm{C}$ & 29 \\
\hline & $\mathrm{NO}_{2}^{-}$ & 233 & 5.5 & 42 & Tris, $\mathrm{pH} 7.4,25^{\circ} \mathrm{C}$ & 30 \\
\hline Ferrous (TPPS) ${ }^{\mathrm{a}}$ & $\mathrm{NO}^{2}$ & $1.8 \times 10^{9}$ & $\sim 0$ & $>10^{9}$ & $\mathrm{H}_{2} \mathrm{O}, \mathrm{pH} 6.5,25^{\circ} \mathrm{C}$ & 22 \\
\hline Ferric(TPPS $)^{\mathrm{a}}$ & NO & $5.0 \times 10^{5}$ & $5.0 \times 10^{2}$ & $10^{3}$ & $\mathrm{H}_{2} \mathrm{O}, \mathrm{pH} 6.5,25^{\circ} \mathrm{C}$ & 31 \\
\hline
\end{tabular}

aTetra(4-sulfonatophenyl)porphine

\section{COLOUR OF FRESH MEAT}

The content of $\mathrm{Mb}$ in skeletal muscle tissue varies within different animal species, e.g. whale $>$ beef $>$ pork $>$ poultry. Moreover, $\mathrm{Mb}$ concentration differs in muscles of the same animal and increases with age, e.g. beef $>$ veal. The fact that whales along with other sea mammals all have relatively high $\mathrm{Mb}$ content in their skeletal muscle tissue is supportive of a function of $\mathrm{Mb}$ as an oxygen storage protein during prolonged periods of diving. Mb has recently also been isolated from human smooth muscle, ${ }^{32}$ and new findings with respect to its role in cardiovascular biology suggest that $\mathrm{Mb}$ may also play other roles in the cells. ${ }^{33}$

In freshly cut meat, the primary pigment is an oxygenated form of ferrous $\mathrm{Mb}, \mathrm{MbFe}^{\mathrm{II}} \mathrm{O}_{2}\left(\mathrm{~d}^{6}\right)$, while a thin layer of the oxidized form metmyoglobin, $\mathrm{MbFe}^{\mathrm{III}} \mathrm{OH}_{2}\left(\mathrm{~d}^{5}\right)$, will exist at a certain depth in the meat followed by the reduced form deoxymyoglobin, $\mathrm{MbFe}^{\mathrm{II}}$ $\left(\mathrm{d}^{6}\right) .{ }^{9}$ The localisation of these three forms of $\mathrm{Mb}$ in raw meat can be visualised as in Figure 2, and the depth of the $\mathrm{MbFe}^{\mathrm{II}} \mathrm{O}_{2}$ ( $x$ in $\mathrm{mm}$ ) will be determined by the partial pressure of oxygen $\left(\mathrm{pO}_{2}\right)$ in the air or headspace of a package surrounding the meat surface and may be calculated from Equation (1):

$x_{\mathrm{MbFe}^{\mathrm{II}} \mathrm{O}_{2}}=\sqrt{\frac{2 \times C_{0} \times D}{A_{0}}}$

where $\mathrm{C}_{\mathrm{o}}$ is total oxygen concentration as determined by $\mathrm{pO}_{2}, \mathrm{D}$ is the diffusion coefficient of $\mathrm{O}_{2}$ and $\mathrm{A}_{\mathrm{o}}$ is the $\mathrm{O}_{2}$ consumption rate due to activity of endogenous enzymes.

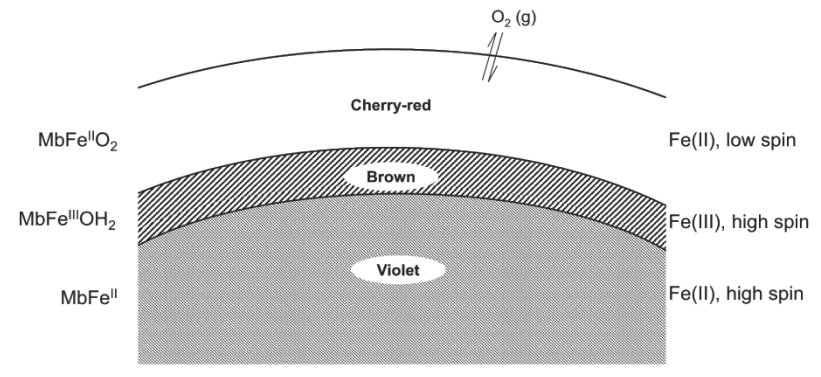

Figure 2. Schematic illustration of myoglobin forms in layers of fresh meat in equilibrium with atmospheric oxygen at the surface showing ligand coordinated and iron atom spin state

The bond formation between ferrous heme iron and $\mathrm{O}_{2}$ involves the p-orbital electrons of the $\mathrm{O}$-atom, and as this ligand has strong electron withdrawing ability the resulting complex has partial ionic character, often described as a partial ferric heme iron with superoxide anion coordinated. ${ }^{8}$ Moreover, this electronic structure of the complex also yields a bent geometry relative to the heme plane and allows the $\mathrm{O}_{2}$ molecule to interact with an amino acid residue (His64) in the protein back-bone present in the distal heme pocket as shown in Figure 3.

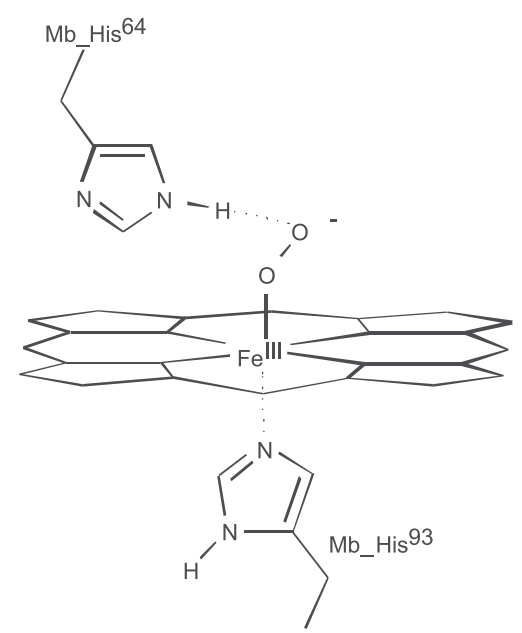

Figure 3. Electronic distribution and metal-ligand geometry of $\mathrm{Fe}-\mathrm{O}_{2}$ in oxymyoglobin illustrating the importance of His binding

The reaction known as autoxidation of $\mathrm{MbFe}^{\mathrm{II}} \mathrm{O}_{2}$ in which the red $\mathrm{Mb}$ derivative is spontaneously oxidized in the presence of molecular oxygen (eq. 2), is quite complex and has received much attention as this process besides being important for meat quality is also crucial in physiology. ${ }^{34}$ Site-directed mutagenesis of $\mathrm{Mb}$ amino acid residues in the heme crevice reveals a pivotal role of these residues in determining the rate of autoxidation. ${ }^{35}$ Particular the His64 has been found important for the robustness as native $\mathrm{MbFe}^{\mathrm{II}} \mathrm{O}_{2}$ has an observed rate constant for autoxidation of $1.5 \times$ $10^{-5} \mathrm{~s}^{-1}$, while a mutant in which His64 was replaced by Ala exhibits a rate constant of $0.016 \mathrm{~s}^{-1}$. The rate of autoxidation of $\mathrm{MbFe}^{\mathrm{II}} \mathrm{O}_{2}$ depends on the oxygen pressure initially showing a sharp linear increase with increasing $\mathrm{pO}_{2}$, passing through a maximal rate at a temperature-dependent $\mathrm{pO}_{2}$, and then leading to a significant decrease in the rate as the $\mathrm{pO}_{2}$ increases further, ${ }^{34}$ as is schematically illustrated in Figure 4. This dependency of the autoxidation rate is consistent with a bimolecular mechanism in which the fraction of $\mathrm{MbFe}^{\mathrm{II}}$ reacts with unbound $\mathrm{O}_{2}$ by an outer-sphere electron transfer yielding $\mathrm{MbFe}^{\mathrm{III}}$ and $\mathrm{O}_{2}{ }^{--}$as seen in Equation 2.

The logarithmic transformed rate constant for autoxidation of $\mathrm{MbFe}^{\mathrm{II}} \mathrm{O}_{2}$ depends linearly on $\mathrm{pH}$ under acidic conditions in support of 


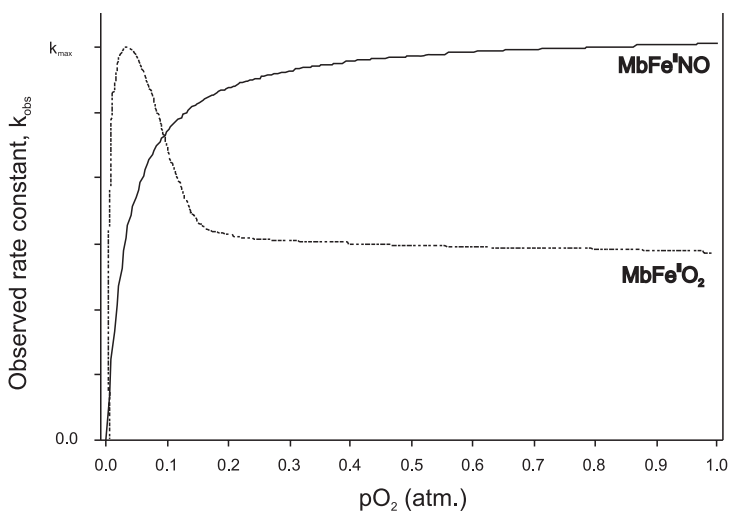

Figure 4. Schematic curves of effect of oxygen partial pressure $\left(\mathrm{pO}_{2}\right)$ on pseudo first order rate constants for autoxidation of $\mathrm{MbFe}^{I I} \mathrm{O}_{2}$ and $\mathrm{MbFe} e^{I I} \mathrm{NO}$

specific-acid catalysis with the stoechiometry shown in eq. $3 .{ }^{36}$ The detailed mechanism is described by a two-state model with a single protolytic group, namely the distal His64 residue that when protonated forms $\mathrm{H}$-bond with coordinated dioxygen and hereby assists in transferring a proton from the solvent to the bound, polarized dioxygen. A positive kinetic salt effect on the specific acid-catalyzed autoxidation of $\mathrm{MbFe}^{\mathrm{II}} \mathrm{O}_{2}$ has been demonstrated, as the rate of proton-assisted nucleophilic replacement of $\mathrm{O}_{2}{ }^{-}$is found to increase with increasing ionic strength. ${ }^{36}$ Porcine $\mathrm{MbFe}^{\amalg} \mathrm{O}_{2}$ reacts with a significant lower rate compared to the $\mathrm{Mb}$ complex isolated from bovine, corvine and ovine species and with different temperature dependence. ${ }^{37}$ For the acidcatalyzed autoxidation of bovine $\mathrm{MbFe}^{\mathrm{II}} \mathrm{O}_{2}$ the reported activation enthalpy $\Delta \mathrm{H}^{\ddagger}=117 \mathrm{~kJ} \mathrm{~mol}^{-1}$ and activation entropy $\Delta \mathrm{S}^{\ddagger}=172 \mathrm{~J} \mathrm{~mol}^{-1} \mathrm{~K}$ ${ }^{1}$ demonstrate a very high activation barrier and a dissociative activation, respectively. ${ }^{36: 37}$ Accordingly, the initial dissociation of oxygen as shown in Equation 2 seems to be rate-determining rather than the subsequent electron transfer to create the superoxide anion radical. The observed kinetic salt effect for the rate of $\mathrm{MbFe}^{\mathrm{II}} \mathrm{O}_{2}$ autoxidation is very similar to that observed for autoreduction of certain hypervalent and prooxidative forms of $\mathrm{Mb}$, as discussed in more detail below.

$$
\begin{aligned}
& \mathrm{MbFe}^{\mathrm{II}} \mathrm{O}_{2} \rightleftharpoons \mathrm{MbFe}^{\mathrm{II}}+\mathrm{O}_{2} \longrightarrow \mathrm{MbFe}^{\mathrm{III}}+\mathrm{O}_{2} \cdot \\
& 4 \mathrm{MbFe}^{\mathrm{II}} \mathrm{O}_{2}+4 \mathrm{H}^{+} \longrightarrow 4 \mathrm{MbFe}^{\mathrm{III}}+3 \mathrm{O}_{2}+2 \mathrm{H}_{2} \mathrm{O}
\end{aligned}
$$

At high hydrostatic pressures, two opposing factors were found to affect the observed rate for autoxidation of $\mathrm{MbFe}^{\mathrm{II}} \mathrm{O}_{2}$ : expansion in the transition state (activation volume $\Delta \mathrm{V}^{\ddagger}$ of $+12.7 \mathrm{ml} \mathrm{mol}^{-1}$ ), is in agreement with the positive value of $\Delta \mathrm{S}^{\ddagger}$ that decreases the rate and a pressure-induced decrease in solution $\mathrm{pH}$ increases the rate. ${ }^{38}$

The electronic structure of the $\mathrm{Fe}^{\mathrm{II}}-\mathrm{O}_{2}$ heme moiety corresponds to a structure with ionic character as shown in Figure 3, in effect resulting in a positive kinetic salt effect at reduced $\mathrm{pH}$ as in meat. During the transformation of muscle tissue to meat, post-mortem anaerobic glycolysis forms lactic acid, which helps to prevent microbial spoilage, but also increases autoxidation and decrease the colour stability. From a meat quality viewpoint, the desirable bright red pigment, $\mathrm{MbFe}^{\mathrm{II}} \mathrm{O}_{2}$, should be protected and preserved during storage, which may be achieved using modified atmosphere packaging with gas mixtures having high $\mathrm{pO}_{2}$ tensions (60-80\%) along with $\mathrm{CO}_{2}(20-$ $30 \%$ ) to inhibit microbial growth. ${ }^{39}$ Moreover, $\mathrm{MbFe}^{\mathrm{II}} \mathrm{O}_{2}$ is very sensitive to light exposure and photooxidation of $\mathrm{MbFe}^{\mathrm{II}} \mathrm{O}_{2}$ is strongly wavelength dependent with quantum yields, as determined using continuous wave photolysis with monochromatic light, having an exponential increase with increasing energy of the irradiation. ${ }^{40}$ Hence, UV-light with $\lambda=254 \mathrm{~nm}$ was found to give a 4,700-fold increase in relative rate of photooxidation in comparison to green light $(\lambda=$ $546 \mathrm{~nm}$ ). Therefore, the wavelength distribution is critical for colour stability as was shown for minced raw beef during frozen storage for which surface discoloration is often encountered (see Table 2). ${ }^{41}$

In raw meat from freshly slaughtered animals the enzyme system metmyoglobin reductase (MMR) is still active and reduces $\mathrm{MbFe}^{\mathrm{III}}$ to the physiological active $\mathrm{MbFe}^{\mathrm{II}}$, which coordinates $\mathrm{O}_{2}$ and reforms the bright red colour. ${ }^{42 ; 43}$ In Figure 5 the so-called colour cycle is shown for fresh meat with various forms of $\mathrm{Mb}$. The colour stability of meat during slaughter, de-boning, storage and retail display depends on post-mortem $\mathrm{pH}$, de-boning/storage temperature, $\mathrm{O}_{2}$ tension, possible addition of salt, packaging and light exposure.

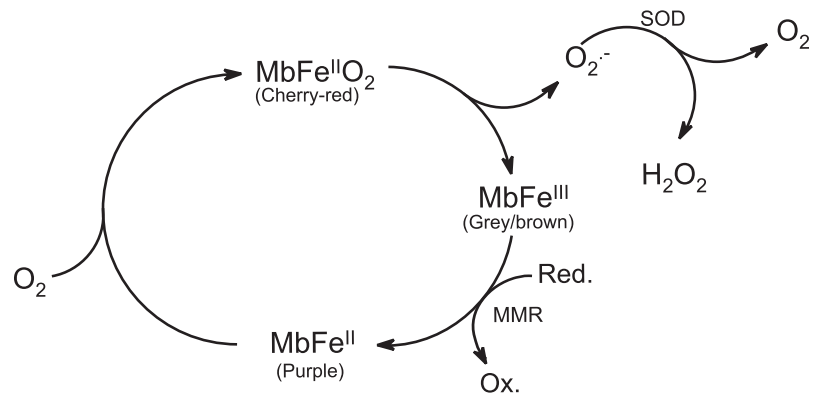

Figure 5. Colour cycle showing interchange of various myoglobin derivatives in fresh meat during storage. The attractive, cherry-red oxymyoglobin $\left(\mathrm{MbFe}^{\mathrm{II}} \mathrm{O}_{2}\right)$ can be oxidised in an uncatalysed reaction into grey/brown metmyoglobin $\left(\mathrm{MbFe}^{I I I}\right)$ and superoxide anion $\left(\mathrm{O}_{2}^{-}\right)$, which assisted by the enzyme superoxide dismutase (SOD) dismutates into oxygen and hydrogen peroxide $\left(\mathrm{H}_{2} \mathrm{O}_{2}\right)$. As long as reducing co-factors are available in raw meat $M b F e^{I I I}$ can be reduced to deoxymyoglobin $\left(\mathrm{MbFe}^{I I}\right)$ by the enzyme system Metmyoglobin Reductase (MMR). This reduced form readily binds molecular oxygen to yield the oxygenated cherry-red form of the pigment

The uncatalyzed autoxidation of $\mathrm{MbFe}^{\mathrm{II}} \mathrm{O}_{2}$ yields $\mathrm{O}_{2}^{-}$as initial reaction product, which will dismutate under the influence of superoxide dismutase (SOD) activity or as a result of acid catalysis generating $\mathrm{H}_{2} \mathrm{O}_{2}$ and $\mathrm{O}_{2} \cdot \mathrm{H}_{2} \mathrm{O}_{2}$ is crucial for formation of prooxidative heme species in meat, ${ }^{44}$ as will be discussed in more detail below.

\section{COLOUR OF CURED MEAT PRODUCTS}

A general review of the chemistry of $\mathrm{Mb}$ and $\mathrm{NO}$ has recently been published, ${ }^{45}$ in which the complex reactions occurring in cured meat products are discussed. The formation of the dominating heme pigment, nitrosylmyoglobin $\left(\mathrm{MbFe}^{\mathrm{II}} \mathrm{NO}\right)$, in nitrite-cured meats involves a complex series of reactions between added nitrate/nitrite and either endogenous or added reductants forming $\mathrm{NO}$ that readily associates to heme $\mathrm{Fe}^{\mathrm{II}}$ in $\mathrm{Mb}^{46}$ The exact reaction pathway from nitrite to $\mathrm{NO}$ in the meat matrix is not fully established, but nitrite initially oxidizes the fresh meat pigment $\mathrm{MbFe}^{\mathrm{II}} \mathrm{O}_{2}$ to $\mathrm{MbFe}^{\mathrm{III}}$, as shown in Equation 4. This reaction is observed as a transient discoloration of the meat surface immediately after the addition of nitrite. The principal nitrosylating agent in cured meat has not been identified yet but several species have been suggested including the acid anhydride of nitrous acid, which, however, is only present in a minute fraction at the normal $\mathrm{pH}$ of meat with a value well above the $\mathrm{pK}_{\mathrm{a}}$ of $\mathrm{HNO}_{2}$. Nitrosylchloride, $\mathrm{NOCl}$, which is known to act as a strong nitrosylating agent, ${ }^{47}$ is more likely the reactant also in the meat matrix where it may be formed following the simultaneous addition of $\mathrm{NaCl}$ and $\mathrm{NaNO}_{2} \cdot{ }^{48}$

$4 \mathrm{MbFe}^{\mathrm{II}} \mathrm{O}_{2}+4 \mathrm{NO}_{2}^{-}+2 \mathrm{H}_{2} \mathrm{O} \longrightarrow 4 \mathrm{MbFe}^{\mathrm{III}} \mathrm{OH}+4 \mathrm{NO}_{3}^{-}+\mathrm{O}_{2}$ 

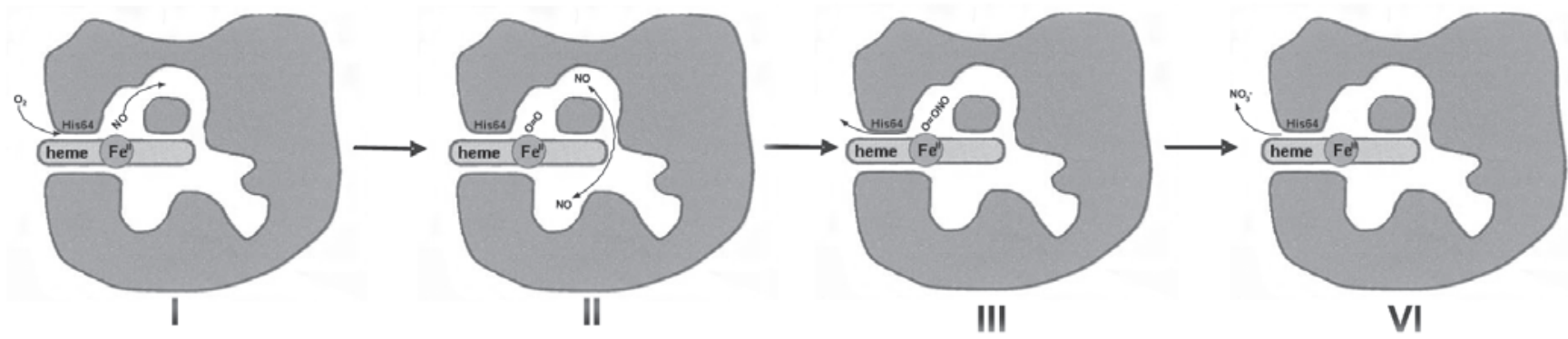

Figure 6. Reaction mechanism suggested for the autoxidation of nitrosylmyoglobin involving two consecutive steps. Schematic drawing of myoglobin molecule was adapted from ref. 54, while the reaction mechanism is depicted according to ref. 53

NO is unique as ligand as it binds to both the ferric and ferrous heme iron in $\mathrm{Mb}$ with equilibrium constants of $1.4 \times 10^{4} \mathrm{M}^{-1}$ and $\geq 10^{11}$ $\mathrm{M}^{-1}$, respectively. ${ }^{22}$ At higher $\mathrm{pH}$ values nitrosylmetmyoglobin $\left(\mathrm{MbFe}^{\mathrm{III}} \mathrm{NO}\right)$ can via nucleophile attack of $\mathrm{OH}^{-}$undergo reductive nitrosylation yielding $\mathrm{MbFe}{ }^{\mathrm{II} N O},{ }^{49}$ although the significance of this pathway is uncertain in the meat matrix. The meat pigment formed during nitrite-curing has been described as a dinitrosyl complex of myoglobin with a NO coordinated both at the distal and proximal side of the heme. ${ }^{46 ; 50}$. The final proof of a pentacoordinate mononitrosyl myoglobin as the principal pigment was presented by Bonnett and coworkers employing electron spin resonance (ESR) spectroscopy. ${ }^{51}$

There is several studies concerned about the chemical reactions of the pigment $\mathrm{MbFe}^{\mathrm{II}} \mathrm{NO}$ in model systems including oxidative degradation under conditions relevant to cured meat products during storage. In contrast to what was found for $\mathrm{MbFe}^{\mathrm{II}} \mathrm{O}_{2}$, autoxidation of $\mathrm{MbFe}^{\mathrm{II}} \mathrm{NO}$ is not sensitive to $\mathrm{pH}$ and to changes in ionic strength as caused by salt addition. The reaction of $\mathrm{MbFe}{ }^{\mathrm{II}} \mathrm{NO}$ with molecular oxygen, known as autoxidation, is a relatively slow reaction, and the pseudo-first rate constant is very similar to the first-order rate constant found for dissociation of $\mathrm{NO}$ from $\mathrm{MbFe}^{\mathrm{II}} \mathrm{NO}$. Accordingly, it was suggested that autoxidation should be described by two consecutive reaction steps, ${ }^{52}$ i.e. initial association of $\mathrm{O}_{2}$ to coordinated $\mathrm{NO}$ forming an intermediate peroxynitrite complex followed by an electron transfer and dissociation of the reaction products. More recent results, however, show that the initial step is a ligand exchange between coordinated $\mathrm{NO}$ and $\mathrm{O}_{2}$ present in solution..$^{53}$ Thus, the rate constant of the initial and rate-determining step exhibits a sharp linear increase in the rate, when $\mathrm{pO}_{2}$ is increased from low to atmospheric pressure, in which saturation is observed (Figure 4). This indicates the ligand exchange to exhibit saturation behaviour with respect to the incoming $\mathrm{O}_{2}$ ligand. The second reaction step has been assigned to a fast bimolecular oxidation of $\mathrm{MbFe}^{\mathrm{II}} \mathrm{O}_{2}$ induced by $\mathrm{NO}\left(\mathrm{k}_{2} \approx 10^{7} \mathrm{M}^{-1} \mathrm{~s}^{-1}\right)$. This reaction is now believed to be important as a clearing pathway for excess NO in mammalian skeletal and cardiac muscle tissue under conditions of nitrosative stress. ${ }^{54}$ The NO molecule initially coordinated to $\mathrm{MbFe}{ }^{\mathrm{II}} \mathrm{NO}$ seems to remain in the vicinity of the heme iron complex of $\mathrm{O}_{2}$ formed as intermediate in the exchange reaction. It further seems possible that $\mathrm{NO}$ is situated within the protein structure in which several cavities have been identified. ${ }^{55}$ It should be noted that NO is not released from the Mb complex into the solvent according to this more detailed mechanism, which was based on additional experiments including bimolecular reactions between $\mathrm{MbFe}^{\mathrm{II}} \mathrm{NO}$ and $\mathrm{MbFe}^{\mathrm{II}} \mathrm{O}_{2} . \mathrm{Mb}$ accordingly seems to serve as a chemical reactor for small molecules like $\mathrm{O}_{2}$ and $\mathrm{NO}$ as is depicted in Figure 6. The more detailed mechanism for autoxidation of $\mathrm{MbFe}{ }^{\mathrm{II}} \mathrm{NO}$ is accordingly suggested to be initiated by an $\mathrm{O}_{2}$ substitution of $\mathrm{NO}$ at the heme iron centre (Figure 6.I). NO is subsequently located in one or more protein cavities, ${ }^{6}$ as has been identified by Xe-binding (Figure 6.II). $\mathrm{NO}$ attacks coordinated $\mathrm{O}_{2}$ from the cavities to form a transient, coordinated ONOO- (Figure 6.III), which subsequently dissociates following isomerisation to nitrate, $\mathrm{NO}_{3}^{-}$, that is expelled from the heme cleft (Figure 6.IV).

Figure 7 shows the involvement of $\mathrm{Mb}$ in the colour cycle of cured meat products, and it includes the possible reformation of the pink form after oxidation to brown $\mathrm{MbFe}^{\mathrm{III}}$. Such colour re-establishment has been observed in studies of colour stability of cooked cured ham during storage, ${ }^{56}$ although the initial colour intensity was never fully restored. ${ }^{56 ; 57}$ The pigment of nitrite-cured meat is much more susceptible to light-induced degradation than the pigment of fresh meat. However, the quantum yield for $\mathrm{MbFe}{ }^{\mathrm{II}} \mathrm{NO}$ shows only moderate wavelength dependence in contrast to $\mathrm{MbFe}^{\mathrm{II}} \mathrm{O}_{2}$, but the quantum yields are several magnitudes higher for $\mathrm{MbFe}{ }^{\mathrm{II}} \mathrm{NO}$ compared to $\mathrm{MbFe}^{\mathrm{II}} \mathrm{O}_{2}$ for wavelength of relevance to food storage (Table 2). ${ }^{40 ; 58}$ Furthermore, the quantum yield for photooxidation of $\mathrm{MbFe}{ }^{\mathrm{II}} \mathrm{NO}$ increases linearly with $\mathrm{pO}_{2},{ }^{58}$ even at very low oxygen tension as demonstrated for the pressure interval $0.0010<\mathrm{pO}_{2}<0.0150$ atmospheres. ${ }^{59}$ Interestingly, a comparison of the stoechiometries for thermal and photo-induced oxidation of $\mathrm{MbFe}^{\mathrm{II}} \mathrm{NO}$ shows as expected a 1:1 stoechiometry for $\mathrm{O}_{2}$ and $\mathrm{MbFe}{ }^{\mathrm{II}} \mathrm{NO}$ during thermal oxidation, while photooxidation results in higher pigment degradation relative to the $\mathrm{O}_{2}$ present. This corresponds to a stoechiometry with approximately $20 \%$ excess degradation of $\mathrm{MbFe}{ }^{\mathrm{II}} \mathrm{NO}$ relative to the $\mathrm{O}_{2}$ present, probably due to involvement of radical intermediates and chain reactions.

Evidence of damage to apomyoglobin (apoMb) during thermal

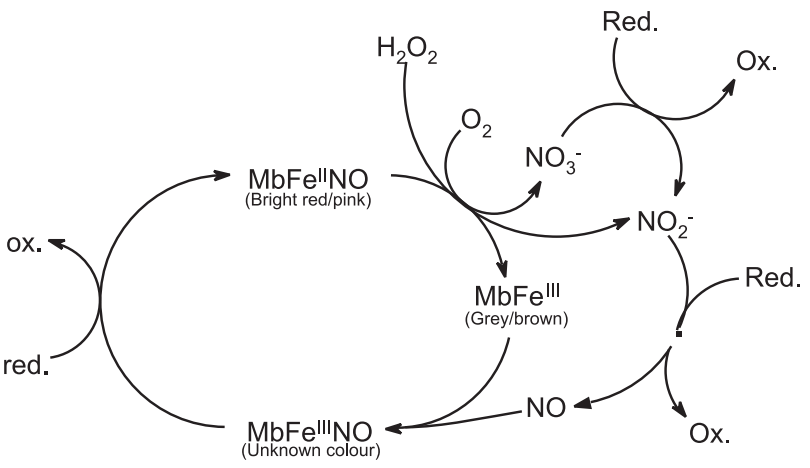

Figure 7. Colour cycle of myoglobin derivatives in cured meat during storage. The attractive pink nitrosylmyoglobin $\left(\mathrm{MbFe}{ }^{I I} \mathrm{NO}\right)$ can be oxidised both by $\mathrm{H}_{2} \mathrm{O}_{2}$ or by molecular oxygen (autoxidation) to yield grey/brown metmyoglobin ( $\mathrm{MbFe}^{\text {III }}$ ) and nitrite or nitrate, respectively. In meat added reducing agents the pools of nitrate/nitrite can be reduced back to $N O$, which binds to metmyoglobin yielding the complex nitrosylmetmyoglobin $\left(\mathrm{MbFe}^{I I I} \mathrm{NO}\right)$. This complex can undergo reduction, thereby returning to $M b F e^{I I} N O$. During storage of nitrite-cured meats such discoloration followed by reformation of pink pigment is directly observable 
Table 2. Quantum yields and relative rates for photooxidation of oxymyoglobin and nitrosylmyoglobin exposed to monochromatic irradiation at $15^{\circ} \mathrm{C}$

\begin{tabular}{lcrcr}
\hline & \multicolumn{2}{c}{$\mathrm{MbFe}^{\mathrm{II}} \mathrm{O}_{2}{ }^{\mathrm{a}}$} & \multicolumn{2}{c}{$\mathrm{MbFe}^{\mathrm{II}} \mathrm{NO}^{\mathrm{b}}$} \\
$(\mathrm{nm})$ & $\begin{array}{c}\Phi_{\text {irr }} \\
\left(\mathrm{mol} \mathrm{einstein}{ }^{-1}\right)\end{array}$ & $\begin{array}{c}\text { Relative } \\
\text { rate }\end{array}$ & $\begin{array}{c}\Phi_{\text {irr }} \\
(\text { mol einstein }\end{array}$ & $\begin{array}{c}\text { Relative } \\
\text { rate }\end{array}$ \\
\hline 254 & $1.6 \times 10^{-2}$ & 4700 & $6.9 \times 10^{-3}$ & 41 \\
313 & $7.9 \times 10^{-4}$ & 150 & $2.3 \times 10^{-3}$ & 7 \\
334 & $1.8 \times 10^{-4}$ & 50 & $1.6 \times 10^{-3}$ & 6 \\
366 & $3.9 \times 10^{-5}$ & 10 & $1.5 \times 10^{-3}$ & 7 \\
405 & $1.2 \times 10^{-5}$ & 12 & $1.1 \times 10^{-3}$ & 14 \\
436 & $7.0 \times 10^{-6}$ & 3 & $8.6 \times 10^{-4}$ & 7 \\
546 & $7.0 \times 10^{-6}$ & 1 & $4.3 \times 10^{-4}$ & 1 \\
\hline
\end{tabular}

${ }^{\mathrm{a}}$ Results from ref. 41 ; ${ }^{\mathrm{b}}$ results from ref. 59

oxidation of $\mathrm{MbFe}^{\mathrm{II}} \mathrm{NO}$ has also been presented as repeated oxidation and nitrosylation of $\mathrm{MbFe}{ }^{\mathrm{II}} \mathrm{NO}$ after several cycles has been found to yield hemichrome, a denatured ferric $\mathrm{Mb}$ form with two His residues bound to the central iron atom, ${ }^{60}$ which is detectable by ESR spectroscopy.

\section{MYOGLOBIN AND OXIDATIVE PROCESSES IN BIOLOGICAL SYSTEMS}

The redox-activities involved in the discoloration of both fresh meat and nitrite-cured meat products affect the oxidative stability of the lipid fraction of the product, as iron redox cycling seems to initiate peroxidation and formation of low-molecular weight compounds responsible for off-flavours and rancidity. The interaction between meat discoloration and lipid oxidation in meat involves the brown $\mathrm{MbFe}^{\mathrm{III}}$, which has been found to have pseudoperoxidase activity and which forms several prooxidative $\mathrm{Mb}$ species during the catalytic cycle following reaction with $\mathrm{H}_{2} \mathrm{O}_{2}$ and other peroxides. $\mathrm{MbFe}^{\mathrm{III}}$ also takes part in the propagation of lipid peroxidation by cleavage of lipid hydroperoxides. ${ }^{44} \mathrm{H}_{2} \mathrm{O}_{2}$ is central in triggering of processes leading to oxidative rancidity in fresh meat, as $\mathrm{O}_{2}^{--}$formed during autoxidation of $\mathrm{MbFe}^{\mathrm{II}} \mathrm{O}_{2}$ yields $\mathrm{H}_{2} \mathrm{O}_{2}$ either spontaneously or mediated by SOD. In addition, $\mathrm{H}_{2} \mathrm{O}_{2}$ may also be produced in significant quantities as a result of growth of the catalase-negative lactic acid bacteria on the meat surface.

Transition metal redox couples such as $\mathrm{Fe}^{\mathrm{III}} / \mathrm{Fe}^{\mathrm{II}}$ or $\mathrm{Cu}^{\mathrm{II}} / \mathrm{Cu}^{\mathrm{I}}$ have standard reduction potentials allowing catalytic decomposition of lipid hydroperoxides (LOOH) to form LO` radicals (Equation 5), and can thereby initiate the chain reaction characteristic for lipid autoxidation. Heme proteins or free heme groups released from proteins also have the ability to enhance lipid peroxidation processes, ${ }^{60}$ and $\mathrm{Mb}$ has been active in this respect especially under acidic conditions. Mb reacts with $\mathrm{H}_{2} \mathrm{O}_{2}$ in a two-electron process in which a hypervalent perferrylmyoglobin, ${ }^{\circ} \mathrm{MbFe} e^{\mathrm{IV}}=\mathrm{O}$, is formed with a tyrosyl radical at Tyr103 (Equation 6). The initially formed hypervalent $\mathrm{Mb}$ then undergoes the so-called autoreduction to form ferrylmyoglobin, $\mathrm{MbFe}^{\mathrm{IV}}=\mathrm{O} .{ }^{61}$ Both of these hypervalent $\mathrm{Mb}$ species are known to initiate lipid peroxidation by hydrogen abstraction from fatty acids. ${ }^{62}$ However, it should be noted that free heme per se has a higher pseudoperoxidase activity compared to protein bound heme. ${ }^{63}$

$$
\begin{aligned}
& \mathrm{LOOH}+\mathrm{Fe}^{2+} \longrightarrow \mathrm{LO}^{\bullet}+\mathrm{OH}^{-}+\mathrm{Fe}^{3+} \\
& \mathrm{MbFe}^{\mathrm{III}}+\mathrm{H}_{2} \mathrm{O}_{2} \longrightarrow \mathrm{MbFe}^{\mathrm{IV}}=\mathrm{O}+\mathrm{H}_{3} \mathrm{O}^{+} \longrightarrow \mathrm{MbFe}^{\mathrm{IV}}=\mathrm{O}
\end{aligned}
$$

Not surprisingly, it has been shown that phenolic acids, known as efficient antioxidants, inhibit the $\mathrm{MbFe}{ }^{\mathrm{II}} / \mathrm{H}_{2} \mathrm{O}_{2}$ induced oxidation of low-density lipoproteins. ${ }^{64}$ More intriguing is the finding that free fatty acids seem to prevent formation of activated hypervalent forms of $\mathrm{Mb}^{65}$ and hemoglobin $(\mathrm{Hb})^{66}$ favouring formation of the inactive hemichromes, as shown in Figure 8 for $\mathrm{Mb}$. This inhibitory effect of free fatty acids on the formation of hypervalent $\mathrm{Mb}$ species has been investigated for conditions of excess of saturated fatty acids. Stearic acid and palmitic acid were both found to reduce ${ }^{\mathrm{M}} \mathrm{MbFe} \mathrm{IV}^{\mathrm{IV}}=\mathrm{O}$ formation from $\mathrm{MbFe}^{\mathrm{III}}$ and $\mathrm{H}_{2} \mathrm{O}_{2}$, while similar quantities of the monounsaturated oleic acid did not affect the $\mathrm{MbFe}^{\mathrm{IV}}=\mathrm{O}$ formation. ${ }^{67}$ However, it is not known whether this antioxidative mechanism is important in biological systems or in muscle-based food products, but free fatty acids have been found to increase in concentration during ischemia reperfusion, ${ }^{68}$ and extensive lipolysis also occurs during long maturation of dry-cured meat products, which attain an exceptional good oxidative stability. ${ }^{69 ; 0}$ In this context, it should be noted that $\mathrm{C}_{8}-\mathrm{C}_{14}$ saturated fatty acids recently have been found to inhibit the activity of cyclooxygenase enzymes, which are responsible for initiating inflammation processes in the body. ${ }^{71}$

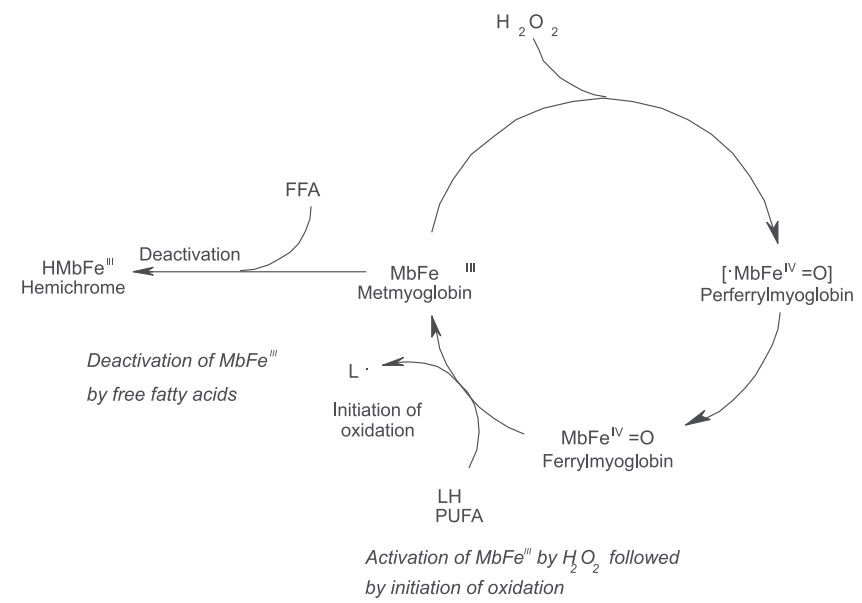

FFA $=$ free fatty acids $;$ PUFA $=$ polyunsatured fatty acids

Figure 8. Prooxidative cycle of $\mathrm{Mb}$ activated by $\mathrm{H}_{2} \mathrm{O}_{2}$ and proposed mechanism for inactivation by free fatty acids forming hemichrome

The rate of $\mathrm{MbFe}^{\mathrm{II}} \mathrm{O}_{2}$ autoxidation increases at reduced oxygen tension, ${ }^{36 ; 37}$ which again increases the oxidative stress of membrane lipids, as $\mathrm{O}_{2}^{--}$is a product of $\mathrm{MbFe}^{\mathrm{II}} \mathrm{O}_{2}$ autoxidation. The effect on lipid oxidation of the post-mortem $\mathrm{pH}$ decrease in muscle-based foods ${ }^{60}$ has a parallel in the acidification and reduced oxygen tension occurring in tissue exposed to ischemia reperfusion during surgery, ${ }^{72}$ which also increases autoxidation of oxygenated heme proteins. However, the rate for autoreduction of the prooxidative species, $\mathrm{MbFe}^{\mathrm{IV}}=\mathrm{O}$, has also been found to be subject to specific acid catalysis and is accordingly $\mathrm{pH}$ dependent with a modest temperature dependence corresponding to the activation parameters: $\Delta \mathrm{H}^{\ddagger}=58.5 \mathrm{~kJ} \mathrm{~mol}^{-1}, \Delta \mathrm{S}^{\ddagger}=2.7 \mathrm{~J} \mathrm{~mol}^{-1} \mathrm{~K}^{-}$ ${ }^{1} \cdot{ }^{73}$ A positive kinetic salt effect was also observed for the autoreduction of $\mathrm{MbFe}^{\mathrm{IV}}=\mathrm{O}$ to yield $\mathrm{MbFe} e^{\mathrm{III}}$, and any $\mathrm{MbFe}^{\mathrm{IV}}=\mathrm{O}$ formed in either fresh meat or cured meat products will be deactivated due to the low $\mathrm{pH}$ conditions and the presence of salt in competition with oxidation of the membrane phospholipids.

The effects of glycation of proteins in relation to various physiological dysfunctions is an emerging field within the medical sciences, and the covalent binding of blood glucose to circulating $\mathrm{Hb}$ is involved in several diabetes related pathological conditions. ${ }^{74-76}$ Glycation of $\mathrm{Mb}$ was recently demonstrated to enhance the prooxidative activity of $\mathrm{Mb}$ and to increase release of free iron ion 
from this heme protein. ${ }^{77}$ Similar effects should be studied for meat products with sugar added as flavouring agent or as substrate for microbial starter cultures.

\section{HEME PROTEINS AND NO^ IN OXIDATIVE PROCESSES}

Once initiated, lipid peroxidation, a chain reaction, will be further enhanced by radicals or redox active metals or will be inhibited by free radical scavenging compounds. Both heme proteins and $\mathrm{NO}$ belong to a class of chemical compounds that can be active as promoters or inhibitors of lipid peroxidation, ${ }^{78}$ and their role in lipid peroxidation will be discussed with special focus on the reactivity of $\mathrm{NO}$ towards reaction intermediate in lipid oxidation.

$\mathrm{NO}$ can act as a prooxidant or an antioxidant depending on the concentration of $\mathrm{NO}$ and the absence or presence of $\mathrm{O}_{2} \cdot-79$ NO reacts extremely fast with $\mathrm{O}_{2}^{--}\left(\mathrm{k}_{2}=10^{9} \mathrm{M}^{-1} \mathrm{~s}^{-1}\right)$ and the reaction product is the strong prooxidant peroxynitrite, $\mathrm{ONOO}^{-80}{ }^{80}$ Equimolar fluxes of $\mathrm{O}_{2}{ }^{--}, \mathrm{H}_{2} \mathrm{O}_{2}$ and $\mathrm{NO}$ have been found to enhance the oxidation of a substrate (dihydrorhodamine) in a model system containing $\mathrm{MbFe}^{\mathrm{III}}$, while further increases in NO concentration significantly reduced oxidation via inhibition of ${ }^{\circ} \mathrm{MbFe} e^{\mathrm{IV}}=\mathrm{O} / \mathrm{MbFe}^{\mathrm{IV}}=\mathrm{O}$ formation.$^{81}$ Another study showed that NO protects cardiomyocytes against tert-butyl hydroperoxide-induced formation of non-protein and proteincentered free radical species and concomitant peroxidation of membrane phospholipids, and NO was concluded to be an important antioxidant in heart tissue. ${ }^{82}$ In contrast, NO formation during ischemia reperfusion of hearts isolated from wild-type or NOS knock-out mice showed a contribution of NO to oxidative injury, most likely due to interaction with $\mathrm{O}_{2}{ }^{--83}$ Recent findings with transgenic mice with an over-expression of NOS, which lack Mb in their cardiac tissue, indicate that excessive formation of NO leads to heart insufficiencies, thus suggesting that $\mathrm{Mb}$ under normal circumstances can be an important factor in protecting the heart from nitrosative stress. ${ }^{84}$ Thus, in light of these conflicting results, the role of $\mathrm{NO}$ in heart tissue under oxidative stress still remains to be clarified.

$\mathrm{NO}$ and its interaction with heme iron/Mb has been suggested to prevent oxidative rancidity in nitrite-cured meat. ${ }^{85: 86}$ Oxidative rancidity is seldom encountered in nitrite-cured meat due to the antioxidative capacity of $\mathrm{MbFe}^{\mathrm{II}} \mathrm{NO}$ and possibly also other nitrite-derived compounds. ${ }^{46}$ So far, only few studies have investigated the isolated effect of $\mathrm{MbFe}^{\Pi \mathrm{NO}}$ in oxidative processes, but in a carotene-linoleate model system, it has been found that $2-10 \mu \mathrm{M}$ of $\mathrm{MbFe}^{\mathrm{III}}$ or $\mathrm{MbFe}^{\mathrm{II}} \mathrm{O}_{2}$ acted as a prooxidative species. In contrast, $\mathrm{MbFe}{ }^{\mathrm{II}} \mathrm{NO}$ at all investigated concentrations did not act as a prooxidant, and $\mathrm{MbFe} e^{\mathrm{II}} \mathrm{NO}$ even inhibits the prooxidative effect of $2 \mu \mathrm{M} \mathrm{MbFe}{ }^{\mathrm{III}} .{ }^{87} \mathrm{MbFe}^{\mathrm{II}} \mathrm{NO}$, in presence of excess $\mathrm{MbFe}^{\mathrm{III}}$, has further been found to significantly inhibit oxygen consumption in a lipid peroxidating model system with methyl linoleate as substrate.$^{88} \mathrm{NO}$ has been found to inactivate the highly oxidizing ferryl $\mathrm{Mb}$ species involved in oxidative stress. ${ }^{89}$ The reaction mechanism includes two steps with a rapid initial formation of a reaction intermediate, nitritometmyoglobin ( $\mathrm{MbFe}{ }^{\mathrm{III}} \mathrm{ONO}$ ), which subsequently decays on a longer time scale (Equations 7-8). The second order rate constant for $\mathrm{MbFe}^{\mathrm{IV}}=\mathrm{O}$ and $\mathrm{NO}$ is found to be $1.8 \times 10^{7} \mathrm{M}^{-1} \mathrm{~s}^{-1}$ at $\mathrm{pH} 7.5$ and $20^{\circ} \mathrm{C}$, while the first order rate constant for decay of the reaction intermediate is $3.4 \mathrm{~s}^{-1}$. Thus, it seems that free NO in solution may either inhibit or in the presence of $\mathrm{O}_{2}{ }^{--}$promote lipid peroxidation. However, when NO is bound to $\mathrm{Mb}$, it may act as a bioactive reservoir that can be released to scavenge $\mathrm{OH}^{*}$ or lipid derived radicals.

$\left[\mathrm{MbFe}^{\mathrm{IV}}=\mathrm{O} \rightleftharpoons \mathrm{MbFe}^{\mathrm{III}}=\mathrm{O}^{\bullet}\right]+\mathrm{NO} \longrightarrow \mathrm{MbFe}^{\mathrm{III}} \mathrm{ONO}$

$\mathrm{MbFe}{ }^{\mathrm{III}} \mathrm{ONO} \longrightarrow \mathrm{MbFe}^{\mathrm{III}}+\mathrm{NO}_{2}^{-}$
The ability of nitrite (the oxidation product of NO) to inactivate $\mathrm{MbFe}^{\mathrm{IV}}=\mathrm{O}$ has been found to occur at a markedly lower rate with a second order rate constant between 13-16 $\mathrm{M}^{-1} \mathrm{~s}^{-1}$ determined at ambient temperatures. ${ }^{89 ; 90}$ Activation parameters of $\Delta \mathrm{H}^{\ddagger}=30 \mathrm{~kJ} \mathrm{~mol}^{-1}$ and $\Delta \mathrm{S}^{\ddagger}=-123 \mathrm{~J} \mathrm{~mol}^{-1} \mathrm{~K}^{-1}$ are indicative of an associative activation with a rate-determining intra-molecular electron transfer to yield a cation radical ${ }^{+} \mathrm{MbFe}^{\mathrm{III}}-\mathrm{O}^{-}$.

The strong prooxidant $\mathrm{ONOO}^{-}$has been found to cause rapid conversion of $\mathrm{MbFe}^{\mathrm{II}} \mathrm{O}_{2}$ to $\mathrm{MbFe}^{\mathrm{III}}$ under the conditions expected in muscle foods, and the presence of $\mathrm{CO}_{2}$ and lowering of $\mathrm{pH}$ seem to reduce $\mathrm{MbFe}^{\mathrm{II}} \mathrm{O}_{2}$ degradation slightly. ${ }^{91}$ In the reaction between $\mathrm{MbFe}^{\amalg} \mathrm{O}_{2}$ and $\mathrm{ONOO}^{-}$, it has been found that $\mathrm{ONOO}^{-}$oxidizes the small fraction of deoxygenated $\mathrm{Mb}$ (in equilibrium with $\mathrm{MbFe}^{\mathrm{II}} \mathrm{O}_{2}$ ) to hypervalent ferryl $\mathrm{Mb}$ (Equation 9), while a subsequent reduction by $\mathrm{ONOO}^{-}$yields $\mathrm{MbFe}^{\mathrm{III}}$ and peroxynitrite radical (eq. 10). ${ }^{92}$ The second order rate constants $\left(20^{\circ} \mathrm{C}\right.$ and $\left.\mathrm{pH} 7.3\right)$ are found to be very similar and to have values $5.4 \times 10^{4}$ and $2.2 \times 10^{4} \mathrm{M}^{-1} \mathrm{~s}^{-1}$, respectively.

$$
\begin{aligned}
& \mathrm{MbFe}^{\mathrm{II}}+\mathrm{ONOOH} \longrightarrow \mathrm{MbFe}^{\mathrm{IV}}=\mathrm{O}+\mathrm{HNO}_{2} \\
& \mathrm{MbFe}^{\mathrm{IV}}=\mathrm{O}+\mathrm{HOONO} \longrightarrow \mathrm{MbFe}^{\mathrm{III}}+\mathrm{OONO}^{\circ}+\mathrm{OH}^{-}
\end{aligned}
$$

The effect of $\mathrm{CO}_{2}$ is interesting, since in the presence of $1.2 \mathrm{mM}$ $\mathrm{CO}_{2}$ the rate of the initial reactions step involving $\mathrm{MbFe}^{\mathrm{II}}$ and $\mathrm{ONOO}$ (eq. 9) increases significantly $\left(4.1 \times 10^{5} \mathrm{M}^{-1} \mathrm{~s}^{-1}\right)$, while the rate of the second reaction step remains practically unaltered. ${ }^{93}$ The possible formation of traces of $\mathrm{ONOO}^{-}$during the autoxidation of $\mathrm{MbFe}^{\mathrm{II}} \mathrm{NO}$ should also be considered, and a recent study of this autoxidation reaction demonstrates the initial rate-determining reaction step to be unaffected by varying levels of $\mathrm{CO}_{2}$, while the second reaction step was affected by elevated levels of $\mathrm{CO}_{2}{ }^{.4}$

Analysis of nitrated amino acid residues in $\mathrm{Mb}$ or haemoglobin $\mathrm{Hb}$ ) following exposure to variable amounts of $\mathrm{ONOO}^{-}$shows that only low quantities of 3-nitrotyrosine can be detected after the reaction with the intact heme proteins. ${ }^{95}$ However, when apoMb or a cyano complex of ferric $\mathrm{Mb}$ are submitted to similar treatment, significantly larger yields for 3-nitrotyrosine and even lower quantities of nitrated tryptophan is observed in apoMb indicating that the $\mathrm{Mb}$ heme iron may act as an efficient scavenger of $\mathrm{ONOO}^{-}$, thereby protecting not only its globin part, but also other proteins such as the cytochromes from nitration. This further supports the theory of $\mathrm{Mb}$ as a protector of cellular respiration in addition to the function of $\mathrm{Mb}$ in facilitated diffusion of $\mathrm{O}_{2}$ in muscle tissue. Likewise, in a study of the reaction between $\mathrm{Hb}$ and $\mathrm{ONOO}^{-}$nitrated amino acid residues were not detected, unless large excess of oxidant compounds was added. ${ }^{96} \mathrm{In}$ contrast, when $\mathrm{Hb}$ was incubated with nitrite and $\mathrm{H}_{2} \mathrm{O}_{2}$, nitration of other proteins and apoHb were observed, ${ }^{97}$ and a similar reaction pattern has also been observed for Mb. ${ }^{98}$ However, blocking of the central iron atom via formation of a cyano $\mathrm{Hb}$ complex again showed that it is the pseudo-peroxidase activity of $\mathrm{Hb}$ and other heme proteins that accounts for this nitration mechanism.

The mechanism of the early processes involved in the formation of back-bone protein radicals may also have negative effects on the oxidative status of protein and lipids in meats during maturation and storage. In fact, the above-mentioned findings may have implications for meat products packaged in modified atmosphere (MA) where $\mathrm{CO}_{2}$ is often used to inhibit microbial growth. So far, these mechanisms are quite speculative, as studies have been conducted only in model systems, and their importance in meats or meat products should be investigated in order to fully clarify the role of reactive nitrogen species in oxidative processes taking place for the post-mortem conditions found in muscle foods.

$\mathrm{NO}$ can be formed in fresh meat post-slaughter $(<8 \mathrm{~h})$ as a 
result of remaining activity of NOS in the muscle tissue, ${ }^{99}$ and the concomitant formation of $\mathrm{O}_{2}^{--}$may generate $\mathrm{ONOO}^{-}$, which will initiate oxidative processes degrading both lipids and pigments of fresh meat during the initial handling and storage. ${ }^{91 ; 100}$ However, further studies are needed to fully assess the potential damaging effect of such reactions, also since hypervalent $\mathrm{Mb}$ species so far have not been detected in muscle tissue intended for consumption.

Protein oxidation receives increasing attention in relation to oxidative stress in biological system as it seems linked to certain diseases. For meat and meat products modifications of functional properties due to radical damage of proteins also need to be considered. For model systems containing the free amino acid tyrosine, it has been shown that $\mathrm{MbFe}^{\mathrm{IV}}=\mathrm{O}$ accelerates the formation of dityrosine possibly via formation of tyrosyl radicals followed by dimerization. ${ }^{101}$ Likewise, the strong prooxidant, $\mathrm{ONOO}^{-}$, has been shown to modify specific side chains of amino acid residues in $\mathrm{Hb}$ with long-lived tyrosyl radicals being formed upon exposure of erythrocytes to ONOO- ${ }^{102}$ In addition, the Cys 110 amino acid residue unique to human $\mathrm{Mb}$ has been found to form an initial thiyl radical upon reaction with $\mathrm{ONOO}^{-}$as shown by ESR spin trapping. The final product is, however, either found to be a Mb dimer formed as Tyr103 radicals subsequently form an intermolecular crosslink to another Tyr103 or a 3-nitrotyrosine also in the 103-position. ${ }^{103}$

\section{CONCLUSION}

Colour is an important quality parameter for both fresh meat and nitrite-cured meat products and depends on the redox status and ligand bound to heme iron in $\mathrm{Mb}$. A basic understanding of Mb chemistry is accordingly crucial, and the "inorganic chemistry" of meat should include a quantitative description of $\mathrm{Mb}$ complex formation with small ligands, such as $\mathrm{O}_{2}, \mathrm{NO}, \mathrm{H}_{2} \mathrm{O}$ and $\mathrm{CO}$, and the kinetics of transformations of these complexes under varying conditions of temperature, oxygen pressure, $\mathrm{pH}$, ionic strength and light exposure.

The practical aspect of colour stability of meat and meat products for the meat industry and retail trade has initiated numerous investigations over the last 50 years and an increased understanding of the complex chemistry. The discovery of the physiological importance of $\mathrm{NO}$ and the possible role of hypervalent $\mathrm{Mb}$ and $\mathrm{Hb}$ during oxidative stress have added new perspectives to the dynamic description of electron transfer and ligand exchange reactions of these heme pigments. Other functions of $\mathrm{Mb}$ than oxygen transport and storage seem to be important and these in vivo functions include activity as a pseudo-enzyme in specific muscle tissue similar to NO dioxygenases known from microorganisms. In effect, $\mathrm{Mb}$ acts as a cellular protector against nitrosative stress during excess production of NO. Future research should focus on the role of $\mathrm{Mb}$ as a mediator of reactions between small molecules important as bio-regulators and include investigations of reaction dynamics possibly occurring within the protein structure using time-resolved spectroscopy.

\section{ACKNOWLEDGEMENT}

The continuing support from LMC-Centre of Advanced Food Studies is greatly acknowledged. J. K. S. Møller wishes to thank the Norma and Frode S. Jacobsen Foundation for a travel grant to work $\mathrm{V}$ in Brazil.

\section{REFERENCES}

1. Kagen, L. J.; Myoglobin. Biochemical, Physiological, and Clinical Aspects, Columbia University Press: New York, 1973.

2. Brunori, M.; Trends Biochem. Sci. 2001, 26, 209.

3. Brunori, M.; Trends Biochem. Sci. 2001, 26, 21.
4. Wittenberg, J. B.; Wittenberg, B. A.; J. Exp. Biol. 2003, 206, 2011.

5. Frauenfelder, H.; Fenimore, P. W.; McMahon, B. H.; Biophys. Chem. 2002, 98,35 .

6. Brunori, M.; Biophys. Chem. 2000, 86, 221.

7. Sharma, V. S.; Magde, D.; Methods 1999, 19, 494.

8. Griddings, G. G.; Crit. Rev. Food Nutr. 1977, 9, 81

9. Livingston, D. J.; Brown, W. D.; Food Technol. 1981, May, 244

10. Antonini, E.; Brunori, M.; Hemoglobin and Myoglobin in their Reactions with Ligands, North-Holland Publishing Company: Amsterdam, 1971.

11. Schläfer, H. L.; Gliemann, G.; Basic Principles of Ligand Field Theory, John Wiley \& Sons Ltd.: London, 1969.

12. Enemark, J. H.; Feltham, R. D.; Coord. Chem. Rev. 1974, 13, 339.

13. Richter-Addo, G. B.; Legzdins, P.; Metal Nitrosyls, Oxford University Press: New York, 1992

14. Olson, J. S.; Phillips, G. N.; J. Biol. Chem. 1996, 271, 17593.

15. Springer, B. A.; Sligar, S. G.; Olson, J. S.; Phillips, G. N.; Chem. Rev. 1994, 94, 699

16. Olson, J. S.; Phillips, G. N.; J. Biol. Ing. Chem. 1997, 2, 544

17. Copeland, D. M.; West, A. H.; Richter-Addo, G. B.; Proteins: Struct., Funct., Genet. 2003, 53, 182.

18. Brucker, E. A.; Olson, J. S.; Ikeda-Saito, M.; Phillips, G. N.; Proteins: Struct., Funct., Genet. 1998, 30, 352.

19. Spiro, T. G.; Kozlowski, P. M.; Acc. Chem. Res. 2001, 34, 137.

20. Clarke, M. J.; Gaul, J. B. In Structure and Bonding; Clarke, M. J.; Goodenough, J. B.; Ibers, J. A.; Jørgensen, C. K.; Mingos, D. M. P.; Neilands, J. B.; Palmer, G. A.; Reinen, D.; Sadler, P. J.; Weiss, R.; Williams, R. J. P., eds.; Springer-Verlag: Berlin, 1993.

21. Carducci, M. D.; Pressprich, M. R.; Coppens, P.; J. Am. Chem. Soc. 1997, $119,2669$.

22. Hoshino, M.; Laverman, L. E.; Ford, P. C.; Coord. Chem. Rev. 1999, 187, 75.

23. Andersen, H. J.; Johansen, H. S.; Shek, C. K.; Skibsted, L. H.; Z. Lebensm. Unters. For. 1990, 191, 293.

24. Duprat, A. F.; Traylor, T. G.; Wu, G. Z.; Coletta, M.; Sharma, V. S.; Walda, K. N.; Magde, D.; Biochemistry 1995, 34, 2634.

25. Decatur, S. M.; Franzen, S.; DePillis, G. D.; Dyer, R. B.; Woodruff, W. H.; Boxer, S. G.; Biochemistry 1996, 35, 4939.

26. Dierks, E. A.; Hu, S. Z.; Vogel, K. M.; Yu, A. E.; Spiro, T. G.; Burstyn, J. N.; J. Am. Chem. Soc. 1997, 119, 7316

27. Zhao, Y. D.; Hoganson, C.; Babcock, G. T.; Marletta, M. A.; Biochemistry 1998, 37, 12458 .

28. Migita, C. T.; Salerno, J. C.; Masters, B. S.; Martasek, P.; McMillan, K.; Ikeda-Saito, M.; Biochemistry 1997, 36, 10987.

29. Merryweather, J.; Summers, F.; Vitello, L. B.; Erman, J. E.; Arch. Biochem. Biophys. 1998, 358, 359.

30. Wanat, A.; Gdula-Argasinska, J.; Rutkowska-Zbik, D.; Witko, M.; Stochel, G.; van Eldik, R.; J. Biol. Ing. Chem. 2002, 7, 165.

31. Laverman, L. E.; Hoshino, M.; Ford, P. C.; J. Am. Chem. Soc. 1997, 119, 12663

32. Qiu, Y.; Sutton, L.; Riggs, A. F.; J. Biol. Chem. 1998, 273, 23426.

33. Garry, D. J.; Kanatous, S. B.; Mammen, P. P. A.; Trends Cardiovas. Med. 2003, 13, 111

34. Shikama, K.; Chem. Rev. 1998, 98, 1357

35. Brantley, R. E., Jr.; Smerdon, S. J.; Wilkinson, A. J.; Singleton, E. W.; Olson, J. S.; J. Biol. Chem. 1993, 268, 6995

36. Andersen, H. J.; Bertelsen, G.; Skibsted, L. H.; Acta Chem. Scand. A 1988, $42,226$.

37. Gutzke, D.; Trout, G. R.; J. Agric. Food Chem. 2002, 50, 2673.

38. Bruun-Jensen, L.; Skibsted, L. H.; Meat Sci. 1996, 44, 145.

39. Jakobsen, M.; Bertelsen, G.; J. Muscle Foods 2002, 13, 143.

40. Bertelsen, G.; Skibsted, L. H.; Meat Sci. 1987, 19, 243.

41. Andersen, H. J.; Bertelsen, G.; Skibsted, L. H.; Meat Sci. 1990, $28,87$.

42. Mikkelsen, A.; Juncher, D.; Skibsted, L. H.; Meat Sci. 1999, 51, 155.

43. Mikkelsen, A.; Skibsted, L. H.; Z. Lebensm. Unters. For. 1992, 194, 9.

44. Skibsted, L. H.; Mikkelsen, A.; Bertelsen, G. In Flavors of Meat, Meat Products and Seafoods; Shahidi, F., ed.; Blackie Academic \& Professional: London, 1994.

45. Møller, J. K. S.; Skibsted, L. H.; Chem. Rev. 2002, 102, 1167.

46. Skibsted, L. H. In The Chemistry of Muscle-based Foods; Johnston, D. E.; Knight, M. K.; Ledward, D. A., eds.; The Royal Society of Chemistry: Cambridge, UK, 1992.

47. Koppenol, W. H.; FEBS Lett. 1994, 347, 5

48. Sebranek, J. G.; Fox, J. B. J.; J. Sci. Food. Agric. 1985, 36, 1169

49. Hoshino, M.; Maeda, M.; Konishi, M.; Seki, H.; Ford, P. C.; J. Am. Chem Soc. 1996, 118, 5702.

50. Pegg, R. B.; Shahidi, F.; Nitrite Curing of Meat. The N-Nitrosamine Problem and Nitrite Alternatives, Food \& Nutrition Press, Inc.: Connecticut, 2000. 
51. Bonnett, R.; Chandra, S.; Charalambides, A. A.; Sales, K. D.; Scourides, P. A.; J. Chem. Soc., Perkin Trans 1 1980, 8, 1706.

52. Arnold, E. V.; Bohle, D. S.; Methods Enzymol. 1996, 269, 41.

53. Møller, J. K. S.; Skibsted, L. H.; Chem. Eur .J. 2004, 10, 2291.

54. Frauenfelder, H.; McMahon, B. H.; Austin, R. H.; Chu, K.; Groves, J. T.; Proc. Natl. Acad. Sci. U.S.A. 2001, 98, 2370.

55. Brunori, M.; Gibson, Q. H.; Embo Reports 2001, $2,674$.

56. Møller, J. K. S.; Jensen, J. S.; Olsen, M. B.; Skibsted, L. H.; Bertelsen, G.; Meat Sci. 2000, 54, 399.

57. Andersen, H. J.; Rasmussen, M. A.; Int. J. Food Sci. Technol. 1992, $27,1$.

58. Andersen, H. J.; Skibsted, L. H.; J. Agric. Food Chem. 1992, 40, 1741.

59. Møller, J. K. S.; Bertelsen, G.; Skibsted, L. H.; Meat Sci. 2002, 60, 421.

60. Baron, C. P.; Andersen, H. J.; J. Agric. Food Chem. 2002, 50, 3887.

61. Irwin, J. A.; Ostdal, H.; Davies, M. J.; Arch. Biochem. Biophys. 1999, $362,94$.

62. Giulivi, C.; Cadenas, E.; Methods Enzymol. 1994, 233, 189.

63. Grinberg, L. N.; O’Brien, P. J.; Hrkal, Z.; Free Radical Biol. Med. 1999, $27,214$.

64. Laranjinha, J.; Vieira, O.; Almeida, L.; Madeira, V.; Biochem. Pharmacol. 1996, 51, 395.

65. Baron, C. P.; Skibsted, L. H.; Andersen, H. J.; J. Agric. Food Chem. 2002, $50,883$.

66. Harrington, J. P.; Newton, P.; Crumpton, T.; Keaton, L.; Int. J. Biochem. 1993, 25,665 .

67. Saifutdinov, R. G.; Larina, L. I.; Vakul'skaya, T. I.; Voronkov, M. G.; Electron Paramagnetic Resonance in Biochemistry and Medicine, Kluwer Academic/Plenum Publishers: New York, 2001.

68. Hendrickson, S. C.; St. Louis, J. D.; Lowe, J. E.; Abdelaleem, S.; Mol. Cell. Biochem. 1997, 166, 85.

69. Coutron-Gambotti, C.; Gandemer, G.; Food Chem. 1999, 64, 95.

70. Vestergaard, C. S.; Schivazappa, C.; Virgili, R.; Meat Sci. 2000, 55, 1.

71. Henry, G. E.; Momin, R. A.; Nair, M. G.; Dewitt, D. L.; J. Agric. Food Chem. 2002, 50, 2231.

72. Gunther, M. R.; Sampath, V.; Caughey, W. S.; Free Radical Biol. Med. 1999, 26, 1388.

73. Mikkelsen, A.; Skibsted, L. H.; Z. Lebensm. Unters. For. 1995, 200, 171.

74. Inouye, M.; Mio, T.; Sumino, K.; Clinica Chimica Acta 1999, 285, 35.

75. Inouye, M.; Mio, T.; Sumino, K.; Metabolism 1999, 48, 205.

76. Warren, J. D.; Blumbergs, P. C.; Thompson, P. D.; Muscle \& Nerve 2002, $25,332$.

77. Roy, A.; Sen, S.; Chakraborti, A. S.; Free Radical Res. 2004, 38, 139.
78. Eiserich, J. P.; Patel, R. P.; O’Donnell, V. B.; Mol. Aspects Med. 1998, 19, 221.

79. Hogg, N.; Kalyanaraman, B.; Biochim. Biophys. Acta 1999, 1411, 378

80. Koppenol, W. H.; Redox Report 2001, 6, 339.

81. Jourd 'heuil, D.; Mills, L.; Miles, A. M.; Grisham, M. B.; Nitric Oxide Biol. Chem. 1998, 2, 37.

82. Gorbunov, N. V.; Tyurina, Y. Y.; Salama, G.; Day, B. W.; Claycamp, H. G.; Argyros, G.; Elsayed, N. M.; Kagan, V. E.; Biochem. Biophys. Res. Commun. 1998, 244, 647.

83. Flogel, U.; Decking, U. K. M.; Godecke, A.; Schrader, J.; J. Mol. Cell. Cardiol. 1999, 31, 827.

84. Godecke, A.; Molojavyi, A.; Heger, J.; Flogel, U.; Ding, Z. P.; Jacoby, C.; Schrader, J. R.; J. Biol. Chem. 2003, 278, 21761.

85. Kanner, J.; Harel, S.; Shagalovich, J.; Berman, S.; J. Agric. Food Chem. 1984, 32, 512.

86. Morrissey, P. A.; Tichivangana, J. Z.; Meat Sci. 1985, 14, 175.

87. Kanner, J.; Methods Enzymol. 1996, 269, 218.

88. Møller, J. K. S.; Sosniecki, L.; Skibsted, L. H.; Biochim. Biophys. Acta 2002, 1570, 129.

89. Herold, S.; Rehmann, F. J. K.; J. Biol. Ing. Chem. 2001, 6, 543.

90. Kroger-Ohlsen, M. V.; Skibsted, L. H.; Food Chem. 2000, 70, 209.

91. Connolly, B. J.; Brannan, R. G.; Decker, E. A.; J. Agric. Food Chem. 2002, 50, 5220.

92. Exner, M.; Herold, S.; Chem. Res. Toxicol. 2000, 13, 287.

93. Herold, S.; Exner, M.; Boccini, F.; Chem. Res. Toxicol. 2003, 16, 390.

94. Møller, J. K. S.; Nannerup, L.; Skibsted, L. H.; Meat Sci. 2005, 69, 71.

95. Herold, S.; Shivashankar, K.; Mehl, M.; Biochemistry 2002, 41, 13460

96. Romero, N.; Radi, R.; Linares, E.; Augusto, O.; Detweiler, C. D.; Mason, R. P.; Denicola, A.; J. Biol. Chem. 2003, 278, 44049.

97. Grzelak, A.; Balcerczyk, A.; Mateja, A.; Bartosz, G.; Biochim. Biophys. Acta 2001, 1528, 97.

98. Bourassa, J. L.; Ives, E. P.; Marqueling, A. L.; Shimanovich, R.; Groves, J. T.; J. Am. Chem. Soc. 2001, 123, 5142.

99. Brannan, R. G.; Decker, E. A.; Meat Sci. 2002, 62, 229.

100. Brannan, R. G.; Decker, E. A.; J. Agric. Food Chem. 2001, 49, 3074.

101. Ostdal, H.; Sorensen, G.; Daneshvar, B.; Skibsted, L. H.; Eur. Food Res. Technol. 2003, 216, 23.

102. Minetti, M.; Scorza, G.; Pietraforte, D.; Biochemistry 1999, 38, 2078.

103. Witting, P. K.; Mauk, A. G.; Douglas, D. J.; Stocker, R.; Biochem. Biophys. Res. Commun. 2001, 286, 352. 